\title{
Analysis of Work Accidents Based on K3 Knowledge and Work Behavior at Muhammadiyah Hospital in Ponorogo
}

\begin{abstract}
Rindang Diannita ${ }^{1}$, Indasah ${ }^{2}$, Sandu Siyoto ${ }^{2}$

${ }^{1}$ Magister of Health Study Program of Institut Ilmu Kesehatan STRADA Indonesia

${ }^{2}$ Lecturer of Institut Ilmu Kesehatan STRADA Indonesia

Email:

diannita.rindang@gmail.com

Received: October 12, 2019

Accepted : February 13, 2020

Occupational health and safety is a component of the hospital that must be considered by the hospital. The purpose of his research was to find out related to the occurrence of work accidents based on knowledge of occupational safety and health and the behavior of workers at the Muhammadiyah Hospital. The sampling technique was done by proportional cluster random sampling with a cross sectional approach. The population of all employees working at the Muhammadiyah Hospital. The independent variable is knowledge of occupational safety and health and worker behavior, the dependent variable is work accident, the data is collected by being analyzed by logistic regression test. The results showed that there was an effect of occupational safety and health knowledge on the incidence of workplace accidents (significant value $=0.002<0.05$ ), there was an influence of behavior on the incidence of workplace accidents (significant value $=0.004<0.05$. all aspects of occupational safety and health, and it is recommended that workers comply with the operationalstandards of occupational safety and health procedures at the Muhammadiyah Hospital.
\end{abstract}

Published : May 12, 2020
Keywords: Behavior, Knowledge, Work Accident

This is an open-acces article distributed under the terms of the Creative Commons Attribution-ShareAlike 4.0 International License. 


\section{INTRODUCTION}

Occupational safety and health is an effort to reduce the risk of workplace accidents. The effort is in the form of conformity of workload of workers, behavior of workers, work environment, which aims so that every worker can work safely without risk of endangering himself and others. Work safety is a safety that is closely related to work tools or personal protective equipment, work processes, work environment, and how to do work (Suwardi and Daryanto, 2018).

Occupational health and safety in hospitals is an effort to guarantee and protect the safety of workers in the hospital, for patients, for visitors, and for the hospital environment in order to prevent workplace accidents in hospitals (Permenkes Republik Indonesia, 2016).

According to Rudyarti (2017) there is a significant correlation between occupational health and safety and the use of personal protective equipment for the incidence of workplace accidents in the workplace, where occupational safety and health knowledge has contributed $16 \%$ and the use of personal protective equipment has contributed $22 \%$ the incidence of workplace accidents. Where there is a relationship between knowledge of occupational safety and health and the use of personal protective equipment contributes $35.6 \%$ to the incidence of workplace accidents (Rudyarti, 2017).

Work accidents according to Fauzi (2017) show that the level of knowledge with the behavior of using personal protective equipment are interconnected, where the level of knowledge of occupational safety and health is the most influential and there is a significant relationship between the level of knowledge of occupational safety and health and supervision of the use of protective equipment yourself (Fauzi, 2017).

According to Istih (2017) most workplace accidents occur due to unsafe actions of workers, the type of unsafe actions that are often carried out by workers, namely operating work equipment that does not conform to standards, and the highest number of occupational accidents, namely musculoskeletal disorders due to the wrong position at work. This is caused by the indiscipline of workers and has not worked in accordance with the applicable standard operating procedures in the hospital.

Meanwhile, according to Yudhawan (2017) work accidents tend to occur because of the relationship between personal factors, namely lack of knowledge of workers related to occupational safety and health, its relation to non-compliance in the use of personal protective equipment, and fatigue when doing work.

The risks caused by workplace accidents are unpredictable, therefore there is a need for workers to be aware of occupational safety and health in order to minimize and even avoid these risks. Occupational safety and health are conditions that can provide safety and health for workers both at work, for their work, agencies, companies, and for the community as well as the surrounding environment. Occupational safety and health is a precautionary measure for any unsafe actions and conditions, which can lead to workplace accidents (Suwardi and Daryanto, 2018).

The Muhammadiyah Hospital in Ponorogo has carried out efforts to Safety and Health (K3) work, which have fire prevention and control facilities, one of which is fire extinguisher, fire alarm, has management of Hazardous and Toxic Materials (B3) from occupational safety and health aspects, has hospital infrastructure from the aspect of safety, as well as having human resources in the field of occupational safety and health of the hospital with an occupational health and safety education background.

Data related to work accidents at Muhammadiyah Hospital shows that there are still incidents of occupational accidents both infectious and non-infectious work accidents, namely needle puncture when giving injection to patients, exposure to blood when cleaning wounds, falling, slipping, stab wounds when taking blood samples, exposure to urine and patient fases when installing a chateter. From these data it is proven that the incidence of work accidents is still a lot.

\section{METHODS}

This study used a qualitative method with a cross sectional approach, the sampling technique was done by proportional cluster random sampling. The population of all employees working at Muhammadiyah Hospital was 324 with a sample of 179 respondents. The independent variable is knowledge of occupational safety and health and worker behavior. 
RESULT

The results showed that there was an influence of occupational safety and health knowledge on the incidence of workplace accidents (significant value $=0.002<0.05$ ) and there was an influence of behavior on the incidence of work accidents (significant value $=0.004<0.05$ ). Presented in the following data:

Table 4.1

Distribution of Frequency of Characteristics of Respondents by Education at Muhammadiyah Hospital in Ponorogo

\begin{tabular}{ccc}
\hline Education & N & $\mathrm{f}(\%)$ \\
\hline Primary School & 1 & 0,6 \\
Junior High School & 5 & 2,8 \\
Senior High School & 49 & 27,4 \\
University & 124 & 69,3 \\
\hline Total & 179 & 100
\end{tabular}

Frequency distribution of respondents' characteristics based on education shows that out of 179 respondents the majority of them were tertiary education (University) which were 124 respondents $(69.3 \%)$.

Table 4.2

Distribution of Frequency of Characteristics of Respondents by Age at Muhammadiyah Hospital in Ponorogo

\begin{tabular}{ccc}
\hline Age & $\mathrm{N}$ & $\mathrm{f}(\%)$ \\
\hline $20-29$ years old & 58 & 32,4 \\
$30-39$ years old & 74 & 41,3 \\
$40-49$ years old & 33 & 18,4 \\
$50-59$ years old & 14 & 7,8 \\
\hline Total & 179 & 100 \\
\hline
\end{tabular}

The frequency distribution of respondents' characteristics by age shows that of the 179 respondents almost half were aged between 30 - 39 years old, namely 74 respondents (41.3\%).

Table 4.3

Frequency Distribution of Occupational Safety and Health Knowledge at Muhammadiyah Hospital in Ponorogo

\begin{tabular}{ccc}
\hline Knowledge & $\mathrm{N}$ & $\mathrm{f}(\%)$ \\
\hline Good & 150 & 83,8 \\
Enough & 29 & 16,2 \\
Less & 0 & 0,0 \\
Not Good & 0 & 0,0 \\
\hline Total & 179 & 100 \\
\hline
\end{tabular}

The frequency distribution of occupational safety and health knowledge at Muhammadiyah Hospital shows that of the 179 respondents most of whom had good occupational health and safety knowledge as many as 150 respondents $(83.8 \%)$.

Table 4.4

Distribution of Frequency of Worker Behavior in Hospitals Muhammadiyah Ponorogo

\begin{tabular}{ccc}
\hline Behavior & $\mathrm{N}$ & $\mathrm{f}(\%)$ \\
\hline Good & 142 & 79,3 \\
Enough & 37 & 20,7 \\
Less & 0 & 0,0 \\
Not Good & 0 & 0,0 \\
\hline Total & 179 & 100 \\
\hline
\end{tabular}

The behavior frequency distribution of Muhammadiyah Hospital workers shows that of the 179 respondents most of them had good behavior as many as 142 respondents (79.3\%). 


\section{Cross Tabulation of General Data and Special Data with Work Accidents at Muhammadiyah Hospital}

Table 4.5

Cross Tabulation of Education with Work Accidents at Muhammadiyah Hospital

\begin{tabular}{|c|c|c|c|c|c|}
\hline \multirow{3}{*}{ Education } & \multicolumn{4}{|c|}{ Work Accident } & \multirow{3}{*}{$\mathrm{P}$} \\
\hline & \multicolumn{2}{|c|}{ Never } & \multicolumn{2}{|c|}{ Ever } & \\
\hline & $\mathrm{N}$ & $\mathrm{f}(\%)$ & $\mathrm{N}$ & $\mathrm{f}(\%)$ & \\
\hline Primary School & 0 & 0,0 & 1 & 0,6 & \\
\hline Junior High School & 2 & 1,1 & 3 & 1,7 & \\
\hline Senior High School & 38 & 21,2 & 11 & 6,1 & 0,000 \\
\hline University & 124 & 69,3 & 0 & 0,0 & \\
\hline Total & 164 & 91,6 & 15 & 8,4 & \\
\hline
\end{tabular}

Cross-Tabulation of Education with workplace accidents shows that of the 179 respondents most of whom were college educated (PT) had never experienced a work accident as many as 124 respondents $(69.3 \%)$ and from the Chi-Square test $p=0,000$ means that there were the relationship between education and work accident at Muhammadiyah Hospital.

Table 4.6

Age Cross Tabulation with Work Accidents at Muhammadiyah Hospital in Ponorogo

\begin{tabular}{|c|c|c|c|c|c|}
\hline \multirow{3}{*}{ Age } & \multicolumn{4}{|c|}{ Work Accident } & \multirow{3}{*}{$\mathrm{P}$} \\
\hline & \multicolumn{2}{|c|}{ Never } & \multicolumn{2}{|c|}{ Ever } & \\
\hline & $\mathrm{N}$ & $f(\%)$ & $\mathrm{N}$ & $f(\%)$ & \\
\hline $20-29$ years old & 52 & 29,1 & 6 & 3,4 & \\
\hline $30-39$ years old & 71 & 39,7 & 3 & 1,7 & 0251 \\
\hline $40-49$ years old & 28 & 15,6 & 5 & 2,8 & 0,201 \\
\hline $50-59$ years old & 13 & 7,3 & 1 & 0,6 & \\
\hline Total & 164 & 91,6 & 15 & 8,4 & \\
\hline
\end{tabular}

Age cross tabulation with workplace accidents shows that out of 179 respondents almost half of those aged 30 - 39 years old have never had a work accident as many as 71 respondents (39.7\%) and from the Chi-Square test $\mathrm{p}=0.251$ means that there is no relationship between age and work accident at Muhammadiyah Hospital.

Table 4.7

Cross Tabulation of Occupational Health and Safety (K3) Knowledge with Work Accidents at Muhammadiyah Hospital in Ponorogo

\begin{tabular}{ccccccccc}
\hline \multirow{2}{*}{ Knowledge } & \multicolumn{9}{c}{ Work Accident } & \multicolumn{2}{c}{ Ever } & $\mathrm{p}$ & OR & \multicolumn{2}{c}{ IK (95\%) } \\
\cline { 2 - 9 } & $\mathrm{N}$ & $\mathrm{f}(\%)$ & $\mathrm{n}$ & $\mathrm{f}(\%)$ & & & Min & Max \\
\cline { 2 - 9 } & 147 & 82,1 & 3 & 1,7 & & & & \\
Good & 17 & 9,5 & 12 & 6,7 & 0,000 & 34,588 & 8,867 & 134,916 \\
Enough & 0 & 0,0 & 0 & 0,0 & & & & \\
Less & 0 & 0,0 & 0 & 0,0 & & & & \\
Not Good & 164 & 91,6 & 15 & 8,4 & & & & \\
\hline Total & 16 &
\end{tabular}

Cross tabulation of occupational safety and health knowledge with workplace accidents shows that of the 179 respondents most of whom have good occupational health and safety knowledge have never experienced work accidents as many as 147 respondents $(82.1 \%)$ and from the Chi-Square test $\mathrm{p}$ $=0,000(\mathrm{OR}=34,588)$ which means that there is a relationship between $\mathrm{K} 3$ knowledge and work accident at Muhammadiyah Hospital. 
Table 4.8

Cross Tabulation of Occupational Accident Behavior at Muhammadiyah Hospital in Ponorogo

\begin{tabular}{|c|c|c|c|c|c|c|c|c|}
\hline \multirow{3}{*}{ Behavior } & \multicolumn{4}{|c|}{ Work Accident } & \multirow{3}{*}{$\mathrm{P}$} & \multirow{3}{*}{ OR } & \multirow{2}{*}{\multicolumn{2}{|c|}{ IK (95\%) }} \\
\hline & \multicolumn{2}{|c|}{ Never } & \multicolumn{2}{|c|}{ Ever } & & & & \\
\hline & $\mathrm{N}$ & $\mathrm{f}(\%)$ & $\mathrm{n}$ & $f(\%)$ & & & Min & Max \\
\hline Good & 140 & 78,2 & 2 & 1,1 & & & & \\
\hline Enough & 24 & 13,4 & 13 & 7,3 & 0000 & 27017 & 8045 & 178714 \\
\hline Less & 0 & 0,0 & 0 & 0,0 & 0,000 & $3 /, 91 /$ & 8,045 & $1 / 8, / 14$ \\
\hline Not Good & 0 & 0,0 & 0 & 0,0 & & & & \\
\hline Total & 164 & 91,6 & 15 & 8,4 & & & & \\
\hline
\end{tabular}

Cross-tabulation of behavior with workplace accidents shows that of 179 respondents most of them had good behavior never had a work accident as many as 140 respondents (78.2\%) and from the Chi-Square test $\mathrm{p}$ value $=0,000(\mathrm{OR}=37,917)$ which means that there is a relationship between behavior and workplace accidents at Muhammadiyah Hospital.

\section{DISCUSSION}

\section{Effect of K3 knowledge on workplace accidents at the Muhammadiyah Hospital}

Based on the results of this study indicate that of the 179 respondents most of whom had good occupational health and safety knowledge and had never experienced a work accident as many as 147 respondents $(82.1 \%)$ and the results of hypothesis testing for knowledge variables K3 (X1) significant value $0.002<0.05$, thus Ho is rejected, then there is the effect of $\mathrm{K} 3$ knowledge on the incidence of workplace accidents at Muhammadiyah Hospital.

The results of the study showed that from 179 respondents most of them had good K3 knowledge as many as 150 respondents (83.8\%). The results of cross tabulation Knowledge of K3 with workplace accidents at Muhammadiyah Hospital showed that of 179 respondents most of whom had good K3 knowledge had never had a work accident as many as 147 respondents $(82.1 \%)$ and from the Chi-Square test obtained $\mathrm{p}$ value $=0,000(\mathrm{OR}=34,588)$ which means that there is a relationship between K3 knowledge and work accident at Muhammadiyah Hospital.

The results of this study are in line with the research of Yusika Vienta Yudhawan and Endang Dwiyanti (2017) in their research entitled Relationship of Personal Factors with Unsafe Actions in Welding Workers at PT. Dock And Shipping Surabaya is a relationship between unsafe actions and workplace accidents where based on the results of research that has been carried out, the K3 Knowledge studied relates to information that is known by welding workers regarding occupational safety and health, workplace accidents, hazards that can arise from welding work, use Personal Protective Equipment (PPE), and Standard Operating Procedure (SOP). Based on the results of the study it can be seen that welding workers with a poor level of OHS knowledge tend to carry out high unsafe actions.

Knowledge of K3 influences the incidence of work accidents because workplace accidents can be caused by dangerous behavior (unsafe action) which is defined by Tulus Wina. Rumah Sakitnu (2018) is a mistake associated with recognizing, perceiving, deciding, and being able to avoid a danger. The ability to recognize and perceive a danger to be avoided be a hospital sick from personal experience or other people (Notoatmojo, 2016).

In the theory of Two Main Factor Teory owned by H.W Heinrich cited by Kuswara (2014), work accidents can occur due to factors that are dangerous (unsafe action) from human factors, namely lack of knowledge related to K3. The lesser K3 knowledge, the higher the work accident or vice versa. In order for workers to have adequate OSH knowledge, then OHS-related policies must be documented which means not only in the form of verbal appeal but made in writing so that they are known and read by all parties. In addition, it is also communicated to all employees or officers with the aim that they understand the objectives of the Occupational Safety and Health (K3) policy in order to reduce the number of work accidents.

In this study, it was shown that knowledge of Occupational Safety and Health (K3) in workers at the Muhammadiyah Hospital had an influence on the incidence of workplace accidents. Thus efforts are needed to provide insight into knowledge related to Occupational Safety and Health (K3) to workers at the Muhammadiyah Hospital by giving socialization and training related to Occupational Safety and 
Health (K3) to workers related to Occupational Safety and Health, in order to create safety and health at work.

\section{Effect of Behavior on workplace accidents at Muhammadiyah Hospital}

Based on the results of this study indicate that of the 179 respondents most of whom had good behavior never had a work accident as many as 140 respondents $(78.2 \%)$ and the results of hypothesis testing for behavioral variables (X2) significant value $0.004<0.05$, thus Ho is rejected, so there is a behavioral influence on the incidence of workplace accidents at the Muhammadiyah Hospital.

The results showed that of the 179 respondents most of them had good behavior as many as 142 respondents $(79.3 \%)$. The results of cross-tabulation of behavior with workplace accidents at Muhammadiyah Hospital showed that of the 179 respondents most of whom had good behavior never had a work accident as many as 140 respondents (78.2\%) and from the Chi-Square test $p=0,000$ ( OR $=37,917)$ which means that there is a relationship between behavior and workplace accidents at the Muhammadiyah Hospital.

The results of this study are in line with the research of Irlianti and Dwiyanti (2014) Analysis of Workers' Safe Behavior Using the ABC (Antecedent Behavior Consequence) Behavior Model is the result of distributing questionnaires showing that workers have adequate OSH knowledge of safe behavior and Occupational Safety and Health. The workforce also considers that the management commitment given is good enough and the training available can help work safely. In addition, the workforce also agrees to the existence of reward and punishment rules from the company as a consequence of labor behavior. The conclusion that can be drawn is that the safe behavior of labor is a result of the existence of internal and external antecedents.

Behavior affects the incidence of work accidents because according to the theory of Two Factors (Two Main Factor) work accidents can be caused by dangerous behavior (unsafe action) is an action that results in the risk of the occurrence of workplace accidents. For example, using tools that are already in use or not feasible to use or are damaged, do not follow existing safety procedures, etc., which have an effect on the existence of hazards and as a cause of workplace accidents.

Behavior according to Suma'mur (2014), affects workplace accidents that can occur and is caused by mistakes from the workers themselves due to: unnatural behavior such as being too brave, not obeying the instructions that exist, being too reckless, fatigue, because of daydreaming, not can work with others, and lack patience. The worse the behavior of workers will be the higher the work accident or vice versa. In order for workers to have good behavior, workers must implement policies related to OSH so that they can reduce the number of work accidents.

In this study, it was shown that the behavior of workers in Muhammadiyah Hospital had an influence on the incidence of workplace accidents. Thus an effort is needed to apply the safe behavior of workers at the Muhammadiyah Hospital by providing motivation and insight to workers related to Occupational Safety and Health, in order to create safety and health in the workplace.

\section{CONCLUSION}

In this study it can be concluded as follows that there is an influence of $\mathrm{K} 3$ knowledge on the incidence of workplace accidents at Muhammadiyah Hospital (significant value $=0.002<0.05$ ), and there is a behavioral influence on the incidence of workplace accidents at Muhammadiyah Hospital (significant value $=0.004<0.05$ ).

The characteristics of respondents based on education showed that of the 179 respondents the majority had tertiary education (PT) as many as 124 respondents (69.3\%). The frequency distribution of respondents' characteristics by age shows that of the 179 respondents almost half were aged between 30 - 39 years, namely 74 respondents $(41.3 \%)$.

The frequency distribution of Occupational Safety and Health knowledge at Muhammadiyah Hospital shows that of the 179 respondents most of whom had good knowledge of Occupational Health and Safety, as many as 150 respondents (83.8\%). The behavior frequency distribution of Muhammadiyah Hospital workers shows that of the 179 respondents most of them had good behavior, namely 142 respondents $(79.3 \%)$.

Cross-Tabulation of Education with workplace accidents shows that of the 179 respondents most of whom were college educated (PT) had never experienced a work accident as many as 124 respondents $(69.3 \%)$ and from the Chi-Square test $p=0,000$ means that there were the relationship 
between education and work accident at Muhammadiyah Hospital. Age cross tabulation with workplace accidents shows that out of 179 respondents almost half of those aged 30 - 39 years have never had a work accident as many as 71 respondents $(39.7 \%)$ and from the Chi-Square test $p=0.251$ means that there is no relationship between age and work accident at Muhammadiyah Hospital. Cross tabulation of k3 knowledge with workplace accidents shows that of the 179 respondents most of whom have good K3 knowledge have never experienced work accidents as many as 147 respondents $(82.1 \%)$ and from the Chi-Square test $\mathrm{p}=0,000(\mathrm{OR}=34,588)$ which means that there is a relationship between $\mathrm{K} 3$ knowledge and work accident at Muhammadiyah Hospital. Cross-tabulation of behavior with workplace accidents shows that of 179 respondents most of them had good behavior never had a work accident as many as 140 respondents $(78.2 \%)$ and from the Chi-Square test $p$ value $=0,000(\mathrm{OR}=$ 37,917) which means that there is a relationship between behavior and workplace accidents at Muhammadiyah Hospital.

\section{REFERENCES}

Irlianti, A. \& Dwiyanti, E. (2014). Analisis Perilaku Aman Tenaga Kerja Menggunakan Model Perilaku ABC (Antecedent Behavior Consequence). Jurnal Universitas Airlangga.

Fauzi, \& Atmojo, H. (2017). Hubungan Antara Tingkat Pengetahuan Dan Pengawasan Terhadap Perilaku Pemakaian Apd Pada Pekerja Konstruksi Pt Wika Beton Boyolali. Jurnal Universitas Sebelas Maret Surakarta.

Istih, \& Candrawati, W. (2017). Hubungan unsafe action dengan kecelakaan kerja pada perawat di Rumah Sakit Panti Waluya Malang. Jurnal Universitas Tribhuwana Tunggadewi Malang.

Kuswana, \& Sunaryo, W. (2016). Ergonomi dan K3. Bandung. Penerbit PT Remaja Rosdakarya Offset.

Notoatmodjo, \& Soekidjo. (2016). Promosi Kesehatan Dan Perilaku Kesehatan. Jakarta. Penerbit Rineka Cipta.

Peraturan Menteri Kesehatan Republik Indonesia Nomor 66 (2016). Tentang Keselamatan Dan Kesehatan Kerja Rumah Sakit. Pemerintah Republik Indonesia.

Rudyarti, \& Edwina. (2017). Hubungan Pengetahuan Keselamatan Dan Kesehatan Kerja Dan Sikap Penggunaan Alat Pelindung Diri Dengan Kejadian Kecelakaan Kerja Pada Pengrajin Pisau Batik Di Pt. X. Jurnal Universitas Darussalam Gontor.

Suma'mur P.K. (2014). Higiene Perusahaan dan Kesehatan Kerja. Jakarta. Penerbit CV. Sagung Seto.

Suwardi, \& Daryanto. (2018). Pedoman Praktis K3LH Keselamatan dan Kesehatan Kerja dan Lingkungan Hidup. Jakarta. Penerbit Graha Media.

Winarsunu, \& Tulus. (2018). Psikologi Keselamatan Kerja. Malang. Penerbit UMM Press.

Yudhawan, \& Dwiyanti. (2017). Hubungan Personal Factors Dengan Unsafe Actions Pada Pekerja Pengelasan Di PT. Dok Dan Perkapalan Surabaya. Jurnal Universitas Airlangga. 